\title{
Influencing Factors for the Acceptance of 3G Mobile Service in Kathmandu Valley
}

\author{
Anij Tuladhar ${ }^{1}$
}

\begin{abstract}
The mobile industry in recent years has been growing at a speedy pace where the use of cell phone is no longer limited to conventional usage like the voice communication, but has enriched the customer experiences with mobile internet services and other value added services. Along with the growing mobile industry, technology behind it is also changing accordingly. However, the user acceptance of technology depends on various factors that lead to either user acceptance or rejection. This study thus aims to identify the major determining factors that influence the user to use the $3 G$ mobile internet and examines the interrelation among the determinants along with effect of the demographic variable limited to Kathmandu Valley users. The conceptual framework of this study is based on the extended version of Davis (1989)'s technology acceptance model using variables social influence, price perception, perceived usefulness, perceived ease of use, attitude to use and behavior intention. The primary survey is conducted using a set of questionnaire, which produced 180 valid responses from the mobile users in Kathmandu Valley. The reliability of the data from questionnaire is verified with factor analysis and Cronbach's alpha. The result shows that social influence has significant influence on perceived ease of use while it has no significant influence on perceived usefulness. Price perception, on the other hand, influences the perceived usefulness. Similarly, perceived usefulness and perceived ease of use influence the attitude of use, which finally influences the behavioral intention. Along with this, social influence is also found to be the extended factors that can influence the attitude of the users, which in turn affects the behavioral intention. Demographic variables, however in this study, have shown no significant influence on the behavioral intentions. On the whole, the usage of $3 G$ mobile internet service is not seen to be satisfying from the study. The major reasons as surveyed from the users themselves for this lower utilizations seem to be higher data costs, presence of cheaper alternatives for internet like Wi-Fi internet, quick drainage of battery and slow mobile internet service provided by the mobile service providers. Thus, for mobile service providers, internet service providers are their direct competitors for $3 G$ mobile internet services. This paper enhances understanding of user acceptance of $3 G$ mobile internet services.
\end{abstract}

Keywords: technology acceptance model; mobile internet; primary survey and descriptive statistics

1 Er. Tuladhar is a Chief Engineer at Himalaya Television, Nepal. Corresponding Email: anijtuladhar@gmail.com 


\section{Introduction}

The development of cellular mobile service was initially offered with analogue technology in the first generation which was replaced by digital ones in the second generation and now the third generation deploys significant improvement with greatly improved performance and capabilities, particularly for data services. Third generation $(3 \mathrm{G})$ mobile communication technology is characterized by increased bandwidth, reinforced speed and efficiency of data transmission. The first commercial use of $3 \mathrm{G}$ service in Nepal began in 2007 from Nepal Telecom as the first operator to launch it; later the service was also launched by another operator NCell in 2010. From then onwards the utilization of $3 \mathrm{G}$ mobile internet in Nepal began to grow rapidly. It is therefore extremely worthy to understand the interplay of factors involved in the adoption of $3 \mathrm{G}$ mobile services, especially when the service utilization is exponentially growing and the market opportunity is significant.

The major research question about the validity of technology acceptance model in Kathmandu valley is successfully fulfilled by the research objective to determine the influencing factors for the use of $3 \mathrm{G}$ mobile internet service and thus examine the interrelationship among the factors to validate the cognitive process.

The study is limited to users of Kathmandu Valley only and thus the results are limited to specific geographical boundaries. Within this geographic limitation, the findings show social influence has significant influence on perceived ease of use while it has no significant influence on perceived usefulness. Price perception, on the other hand, influences the perceived usefulness. Similarly, perceived usefulness and perceived ease of use influence the attitude of use which finally influences the behavioral intention. Along with this, social influence is also found to be the extended factors that can influence the attitude of the users which in turn affects the behavioral intention. Demographic variables, however in this study, have shown no significant influence on the behavioral intentions.

\section{Review of Literatures}

The study of influencing factors for the acceptance or rejection of technology has been matter of interest for researchers for many years. In this context, Technology Acceptance Model (TAM) was first developed by Davis (1989) taking into consideration two factors: perceived usefulness and perceived ease of use. The model was based on Theory of Reasoned Action (TRA) purposed by Ajzen \& Fishbien (1980) which included behavioral intention, attitude and subjective norms as guiding variables. Behavioral intention is defined here as the strength of one's intention to perform a specific behavior which is a combination of attitude towards performing the behavior and the subjective norm. Later, perceived behavior control was included by Ajzen (1991) in his Theory of Planned Behavior (TPB) which measured the degree to which person feels capable and confident in their ability to execute the desired behavior. 
Malhotra \& Galletta (1999) have explained TAM with extension of social influence which affects the individual resulting in their internalization, identification and compliance with induced behavior. The social influence here is termed as psychosocial attachment. The first extension to TAM purposed by Vishwanath \& Davis (2000) has extended with similar variable with inclusion of social influence and cognitive instrumental process. The social influence is measured with factors like experience, voluntariness, subjective norms and image while the cognitive instrumental process is measured with job relevance, output quality and result demonstrability. Similar unification of various models can be seen in Unified Theory of Acceptance and Use of Technology (UTAUT) by Vishwanath et al. (2003), which used up to eight prominent models.

The other study by Kaaisen (2005) has extended the model with the variables perceived values of service, perceived ease of use, trust and perceived ease of adoption. Pungthong \& Malisawan (2005) have explained the person would be more motivated to do or repeat activities of utilizing $3 \mathrm{G}$ services that are more enjoyable. The study with perceived enjoyment and use context is further presented in different way by Liu \& Li (2010) where the variable are tested in five different stages of innovation adoption namely: innovators, early adaptors, early majority, late majority and laggards. The result shows perceived enjoyment turned out to be more significant predictor of mobile internet use across all innovation stages while use context is only significant in first two stages while compatibility and complexity have more effect on the later stages.

Jongepier (2011) and Kumar \& Sikri (2013) have termed the variable perceived entertainment which influenced the behavioral intention for use of technology. The former study has, however, found that the social pressure does not directly influence behavioral intention but has indirect influence through perceived usefulness and perceived ease of use.

The other study in 3G adoption by Agrawal et al (2007), Abu (2010), Singh \& Singh(2010), Dawadi \& Shrestha (2013), Kumar \& Sikri (2013) and Garg \& Garg(2013) have included price convenience and cost of adaption influences the attitude towards use. Price convenience and service quality are all significant predictors of perceived value and the perceived value has strong relationship with purchase intention. The study also depicts GDP, competition policies and technological innovation also plays as moderating variables while taking price perception as the influencing variable.

Similar study on $3 \mathrm{G}$ adoptions considering the demographic variable can be seen in the research paper of Pan (2011), Chong et al (2012) and Mardikayn, Besireyo \& Uzmaya(2012) which have found the gender has no influence on the behavior intention to use. 
The utilization of $3 \mathrm{G}$ mobile service is, however, seen to have less penetration in various studies of Kuo \& Yen (2009), Suki (2012) and Mahfuz \& Latif (2013). The study has emphasized the consumer usage rate of current $3 \mathrm{G}$ service remained to be low. The reason outlined in case of Bangladesh for poor utilization was the insufficiency of service providers since at first only one telecom operator was permitted to provide $3 \mathrm{G}$ service.

Susilo \& Dahesihsori (2011) research has outlined the similar outcome from their independent study through which they explain although the original TAM was developed in reference to the western society, the model is consistent in Asian society as well. Phuong, Van \& $A n(2015)$ in addition recommend $3 G$ providers should provide more interesting and entertaining contents in their $3 \mathrm{G}$ applications and services which charge appropriate fees and must be easy to use for customers which is the ingredient for behavioral intention to use.

The review of various literature shows that TAM has proven to be the most popular and successful model in determining the acceptance of users towards any information technology system. Some literatures have also extended the TAM model by adding new variables to study the factor influencing the behavioral intention which are statically tested to verify the result. The literatures published by the authors regarding study with TAM as a guiding principle for $3 \mathrm{G}$ mobile service acceptance are valid for the locations they surveyed from. It would not be correct that the proven models are always true and can be significantly applied for different locations and country. Some variations may exist and the dominating factors can vary from locations to locations. The study with extended model including social influence and price perception variables are not been yet studied in case of Kathmandu Valley. Thus, this study intends to fulfill this research gap that whether the factors chosen in the model of this study are significant in case of Kathmandu Valley as well.

\section{The Methodology}

\subsection{Theoretical framework}

The technology acceptance model (TAM) was first purposed by Davis (1989) with perceived usefulness and perceived ease of use as the two factors that determine user's acceptance or rejection of information technology. The model was based on the theory of reasoned action (TRA) proposed by Ajzen \& Fishbien's (1980). Ever since TAM model became increasingly popular among the researchers and extended versions of the original TAM model were being developed with inclusions of concepts from other researches like Theory of Planned Behavior (TPB) by Ajzen (1991), Unified Theory of Acceptance and Use of Technology (UTAUT) by Vishwanath et al. (2003) and other. In overall, the model is used in management science to understand the systematic technology acceptance processes and factors involved for behavioral intention of users to accept it. 
The conceptual framework of the study is formulated by the idea of Garg and Garg (2013). The model applied six variables namely perceived usefulness (PU), perceived ease of use (PEOU), attitude to use (ATU), behavioral intention (BI), social influence (SI), price perception (PP) and a moderating demographic variable (DV) which includes age, gender and income level. Perceived usefulness in this study is the extent people believe it will help them perform their task better. Perceived ease of use is defined as the degree to which person believes that using particular system would be free from effort. Attitude to use is the perception of user towards technology. Behavioral intention is a measure of likelihood that person will adopt the technology. And the extended variables social influence and price perception are the influences generated from the social circles and the cost of services respectively. Theoretically, the factors not just independently influence the behavioral intentions but are interrelated and have both direct and indirect influence as presented in conceptual framework shown in Figure 1.

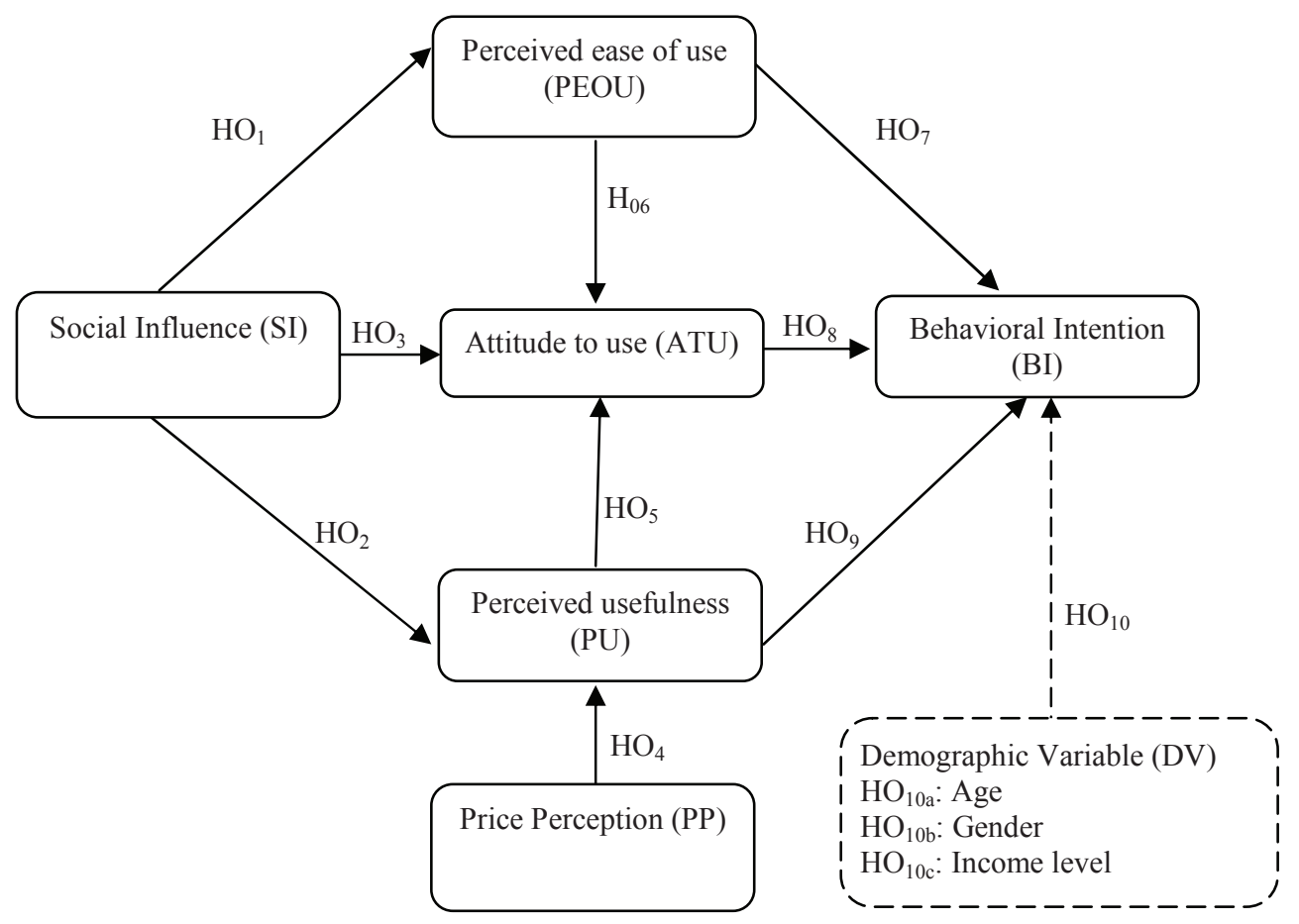

Figure 1. Conceptual framework 
The measurement of the variable is done through questionnaire survey which consists of five point likert scale response. The basic design for the variable measurement purpose is presented in Table 1.

Table 1. Variables, indicators and their code used in the study

\begin{tabular}{|c|c|c|c|}
\hline Variables & Indicators & $\begin{array}{l}\text { Code } \\
\text { Used }\end{array}$ & References \\
\hline $\begin{array}{l}\text { Perceived } \\
\text { Usefulness(PU) }\end{array}$ & $\begin{array}{l}\text { 1. Using } 3 \mathrm{G} \text { mobile services can increase } \\
\text { my productivity. } \\
\text { 2. Using } 3 \mathrm{G} \text { mobile service can enhance } \\
\text { my effectiveness. } \\
\text { 3. Using } 3 \mathrm{G} \text { mobile service can help me } \\
\text { accomplish task and work in life more } \\
\text { easily. } \\
\text { 4. Using } 3 \mathrm{G} \text { mobile service increases } \\
\text { quality of communication. }\end{array}$ & $\begin{array}{l}\text { PU1 } \\
\text { PU2 } \\
\text { PU3 } \\
\text { PU4 }\end{array}$ & $\begin{array}{l}\text { Garg\&Garg } \\
(2013), \text { Kuo\& } \\
\text { Yen (2009) } \\
\text { and Suki } \\
(2012)\end{array}$ \\
\hline $\begin{array}{l}\text { Perceived ease } \\
\text { of use (PEOU) }\end{array}$ & $\begin{array}{l}\text { 1. Learning to use } 3 \mathrm{G} \text { is very simple. } \\
\text { 2. It might be easy to become skillful at } \\
\text { using } 3 \mathrm{G} \text { mobile service. } \\
\text { 3. } 3 \mathrm{G} \text { mobile service might be user } \\
\text { friendly. } \\
\text { 4. It is very easy to get familiarized with } \\
3 \mathrm{G} \text { mobile services. }\end{array}$ & $\begin{array}{l}\text { PEOU1 } \\
\text { PEOU2 } \\
\text { PEOU3 } \\
\text { PEOU4 }\end{array}$ & $\begin{array}{l}\text { Garg\&Garg } \\
\text { (2013) and } \\
\text { Kuo\& Yen } \\
(2009)\end{array}$ \\
\hline $\begin{array}{l}\text { Attitude to use } \\
\text { (ATU) }\end{array}$ & $\begin{array}{l}\text { 1. Using } 3 \mathrm{G} \text { mobile is a good idea. } \\
\text { 2. Using } 3 \mathrm{G} \text { mobile service is pleasant } \\
\text { experience. } \\
\text { 3. Using } 3 \mathrm{G} \text { mobile service is beneficial } \\
\text { to me. } \\
\text { 4. Generally speaking, I like the idea of } \\
\text { using } 3 \mathrm{G} \text { mobile service. }\end{array}$ & $\begin{array}{l}\text { ATU1 } \\
\text { ATU2 } \\
\text { ATU3 } \\
\text { ATU4 }\end{array}$ & $\begin{array}{l}\text { Garg\&Garg } \\
(2013) \text { and } \\
\text { Kuo\& Yen } \\
(2009)\end{array}$ \\
\hline $\begin{array}{l}\text { Behavioral } \\
\text { Intention (BI) }\end{array}$ & $\begin{array}{l}\text { 1. I intend to use } 3 \mathrm{G} \text { mobile service } \\
\text { when the service becomes widely } \\
\text { available. } \\
\text { 2. Whenever possible, I intend to use } 3 \mathrm{G} \\
\text { mobile service. } \\
\text { 3. I will try to use } 3 \mathrm{G} \text { mobile service if } \\
\text { necessary in life and work. }\end{array}$ & $\begin{array}{l}\mathrm{BI} 1 \\
\mathrm{BI} 2 \\
\mathrm{BI} 3 \\
\end{array}$ & $\begin{array}{l}\text { Garg\&Garg } \\
\text { (2013) and } \\
\text { Kuo\& Yen } \\
(2009)\end{array}$ \\
\hline $\begin{array}{l}\text { Social } \\
\text { Influence(SI) }\end{array}$ & $\begin{array}{l}\text { 1. I will use } 3 \mathrm{G} \text { mobile service if the } \\
\text { service is widely used by people in my } \\
\text { community. } \\
\text { 2. I will adopt } 3 \mathrm{G} \text { mobile service if my } \\
\text { supervisors/seniors use it. } \\
\text { 3. I will adopt } 3 \mathrm{G} \text { mobile service if my } \\
\text { friends use it. }\end{array}$ & $\begin{array}{l}\text { SI1 } \\
\text { SI2 } \\
\text { SI3 }\end{array}$ & $\begin{array}{l}\text { Garg\&Garg } \\
(2013)\end{array}$ \\
\hline
\end{tabular}




\begin{tabular}{|c|c|c|c|}
\hline & $\begin{array}{l}\text { 4. I will adopt } 3 \mathrm{G} \text { mobile service if my } \\
\text { family members/relatives use it. }\end{array}$ & SI4 & \\
\hline $\begin{array}{l}\text { Price } \\
\text { Perception(PP) }\end{array}$ & $\begin{array}{l}\text { 1. I intend to use } 3 \mathrm{G} \text { mobile service if it } \\
\text { is inexpensive. } \\
\text { 2. I intend to use } 3 \mathrm{G} \text { mobile service } \\
\text { depending upon the service price. } \\
\text { 3. I think telecom service provider } \\
\text { should reduce price. } \\
\text { 4. For me current } 3 \mathrm{G} \text { mobile tariff is still } \\
\text { high. }\end{array}$ & $\begin{array}{l}\text { PP1 } \\
\text { PP2 } \\
\text { PP3 } \\
\text { PP4 }\end{array}$ & $\begin{array}{l}\text { Garg\&Garg } \\
(2013) \text { and } \\
\text { Kuo\& Yen } \\
(2009)\end{array}$ \\
\hline $\begin{array}{l}\text { Demographic } \\
\text { Variables (DV) }\end{array}$ & $\begin{array}{l}\text { 1. Age } \\
\text { 2. Gender } \\
\text { 3. Income Level }\end{array}$ & $\begin{array}{l}\text { DV1 } \\
\text { DV2 } \\
\text { DV3 }\end{array}$ & - \\
\hline
\end{tabular}

The estimated null hypothesis in the conceptual framework is stated with the statements as presented in Table 2 .

Table 2. The estimated null hypothesis

\begin{tabular}{|l|l|}
\hline $\begin{array}{l}\text { Hypoth } \\
\text { esis }\end{array}$ & Statement \\
\hline $\mathrm{HO}_{1}$ & $\begin{array}{l}\text { There is no significant relationship of social influence (SI) on the perceived ease } \\
\text { of use (PEOU). }\end{array}$ \\
\hline $\mathrm{HO}_{2}$ & $\begin{array}{l}\text { There is no significant relationship of social influence (SI) on the perceived } \\
\text { usefulness (PU). }\end{array}$ \\
\hline $\mathrm{HO}_{3}$ & $\begin{array}{l}\text { There is no significant relationship of social influence (SI) on the attitude to use } \\
\text { (ATU). }\end{array}$ \\
\hline $\mathrm{HO}_{4}$ & $\begin{array}{l}\text { There is no significant relationship of price perception (PP) on the perceived } \\
\text { usefulness (PU). }\end{array}$ \\
\hline $\mathrm{HO}_{5}$ & $\begin{array}{l}\text { There is no significant relationship between perceived usefulness (PU) and } \\
\text { attitude to use (ATU). }\end{array}$ \\
\hline $\mathrm{HO}_{6}$ & $\begin{array}{l}\text { There is no significant relationship between perceived ease of use (PEOU) and } \\
\text { attitude to use (ATU). }\end{array}$ \\
\hline $\mathrm{HO}_{7}$ & $\begin{array}{l}\text { There is no significant relationship between perceived ease of use (PEOU) and } \\
\text { Behavioral Intention (BI). }\end{array}$ \\
\hline $\mathrm{HO}_{8}$ & $\begin{array}{l}\text { There is no significant relationship between attitude to use (ATU) and Behavioral } \\
\text { Intention (BI). }\end{array}$ \\
\hline $\mathrm{HO}_{9}$ & $\begin{array}{l}\text { There is no significant relationship between perceived usefulness (PU) and } \\
\text { Behavioral Intention (BI). }\end{array}$ \\
\hline $\mathrm{HO}_{10 \mathrm{a}}$ & $\begin{array}{l}\text { There is no significant relationship between demographic variable -age (DV1) and } \\
\text { Behavioral Intention (BI). }\end{array}$ \\
\hline $\mathrm{HO}_{10 \mathrm{~b}}$ & $\begin{array}{l}\text { There is no significant relationship between demographic variable - gender (DV2) } \\
\text { and Behavioral Intention (BI). }\end{array}$ \\
\hline $\mathrm{HO}_{10 \mathrm{c}}$ & $\begin{array}{l}\text { There is no significant relationship between demographic variable -income level } \\
\text { (DV3) and Behavioral Intention (BI). }\end{array}$ \\
\hline
\end{tabular}




\subsection{The data}

The primary data for this study is collected from a cross sectional study with the information gathered from respondents through a structured questionnaire. The research is a quantitative study in which hypotheses testing are done to evaluate relationship between different variables in the model. The population for this research is the people of Kathmandu valley who have subscribed $3 \mathrm{G}$ mobile services. The data collection is done with structured questionnaire from 200 sample respondent among which 180 valid responses are used in the study. The samples are chosen based on non-probability sampling technique using convenient sampling methods. The final results drawn from descriptive and inferential analysis conclude the theoretical model applicability for Kathmandu Valley mobile service users.

\subsection{Reliability and validity of the data}

The Kaiser-Meyer-Olkin (KMO) measure of sampling adequacy is used to confirm the appropriateness of proceeding with the analysis to reduce the number of items and indentify the dimensions of latent variables. The key rule used here is to drop the variables which has factor loading of 0.5 or less. Since all of the variables have resulted factor loading above 0.5 , all of them are preserved. KMO measure of sampling adequacy have resulted the value of 0.807 with $p$-value $=0.000$, which represent the reliability of the analysis. Table 3, summarizes the factor loading table that identifies the dimensions of latent variable.

Table 3. Factor loadings with rotated component matrix

\begin{tabular}{|c|c|c|c|c|c|c|}
\hline & & & Comp & & & \\
\hline Variable & 1 & 2 & 3 & 4 & 5 & 6 \\
\hline PU1 & & 0.879 & & & & \\
\hline PU2 & & 0.872 & & & & \\
\hline PU3 & & 0.854 & & & & \\
\hline PU4 & & 0.743 & & & & \\
\hline PEOU1 & & & 0.871 & & & \\
\hline PEOU2 & & & 0.875 & & & \\
\hline PEOU3 & & & 0.829 & & & \\
\hline PEOU4 & & & 0.893 & & & \\
\hline ATU1 & & & & 0.765 & & \\
\hline ATU2 & & & & 0.763 & & \\
\hline ATU3 & & & & 0.837 & & \\
\hline ATU4 & & & & 0.848 & & \\
\hline BI1 & & & & & & 0.758 \\
\hline BI2 & & & & & & 0.695 \\
\hline BI3 & & & & & & 0.824 \\
\hline
\end{tabular}




\begin{tabular}{|l|r|r|r|r|r|r|}
\hline & \multicolumn{9}{|c|}{ Component } \\
\hline Variable & $\mathbf{1}$ & $\mathbf{2}$ & $\mathbf{3}$ & $\mathbf{4}$ & $\mathbf{5}$ & $\mathbf{6}$ \\
\hline SI1 & $\mathbf{0 . 8 0 7}$ & & & & & \\
\hline SI2 & $\mathbf{0 . 9 1 9}$ & & & & & \\
\hline SI3 & $\mathbf{0 . 9 2 9}$ & & & & & \\
\hline SI4 & $\mathbf{0 . 9 3 4}$ & & & & $\mathbf{0 . 7 7 9}$ & \\
\hline PP1 & & & & & $\mathbf{0 . 8}$ & \\
\hline PP2 & & & & & $\mathbf{0 . 8 7 5}$ & \\
\hline PP3 & & & & & & \\
\hline PP4 & & & & & \\
\hline Extraction Method: Principal Component Analysis. & & \\
\hline \multicolumn{2}{|l|}{ Rotation Method: Varimax with Kaiser Normalization. } & & \\
\hline a Rotation converged in 6 iterations. & & & & \\
\hline
\end{tabular}

Table 4. Reliability analysis with Cronbach's Alpha

\begin{tabular}{|l|r|}
\hline Variable & Cronbach's Alpha \\
\hline Perceived Usefulness & 0.919 \\
\hline Perceived Ease of Use & 0.911 \\
\hline Attitude to Use & 0.913 \\
\hline Behavioral Intention & 0.724 \\
\hline Social Influence & 0.931 \\
\hline Price Perception & 0.887 \\
\hline
\end{tabular}

The reliability of scale indicates that the study is free from random error. Internal consistency is measured in this research using Cronbach's coefficient alpha. The statistic provides an indication of the average correlation among all of the items that make up the scale. Its value ranges from 0 to 1 with higher values indicating greater reliability. Table 4 indicates the result of analysis of the Cronbach's Aplha scale for factors: PU, PEOU, ATU, BI, SI and PP are more than 0.7. This indicates that the survey questionnaire responses are reliable to make the analysis.

\subsection{Data analysis methods}

The data analysis of the primary information collected from the questionnaire is done with statistical software SPSS and Ms. Excel. The data analysis portion for this research is divided into two parts. The first one is the descriptive analysis and the other is inferential analysis.

The descriptive analysis is the findings from the research presented in a readable format with tables, charts and its conclusions. The descriptive analysis for this research is done in two distinct parts for simplicity. It is done through demographic profile of respondents and their experience with $3 \mathrm{G}$ mobile service. The findings consist frequency, percentage, mean and standard deviation. 
144 Tuladhar: Influencing Factors for the Acceptance of $3 G$ Mobile Service in Kathmandu Valley

The inferential analysis is the presentation of relation among various variables and testing it against the purposed hypothesis to verify if the sample data can be used to infer about the population. Hypothesis stated for the conceptual model is tested with appropriate tools and is interpreted in this section.

\section{Results and Descriptions}

The result obtained from the study is mentioned under two segments: descriptive statistical analysis where the statistical data is presented and the inferential analysis where the test of hypothesis and their significance to the statement is presented.

\subsection{Descriptive statistical analysis}

Among the 200 questionnaires submitted, 180 responses were valid. The demographic profile of the 180 respondents is summarized in Table 5. The demographic profile of respondents is taken based on gender, age group, education level, occupation and average income. Among which gender, age group and income level are taken for the study as the influential factor for acceptance of $3 \mathrm{G}$ mobile internet service.

Table 5. Demographic profile of respondent

\begin{tabular}{|c|l|r|r|}
\hline Demographic Profile & Category & Frequency & Percent \\
\hline \multirow{4}{*}{ Gender } & Male & 100 & 55.6 \\
\cline { 2 - 4 } & Female & 80 & 44.4 \\
\hline \multirow{5}{*}{ Age group } & 15 to 20 years old & 54 & 30 \\
\cline { 2 - 4 } & 20 to 30 years old & 73 & 40.6 \\
\cline { 2 - 4 } & 30 to 40 years old & 33 & 18.3 \\
\cline { 2 - 4 } & Above 40 years old & 20 & 11.1 \\
\hline \multirow{5}{*}{ Education level } & School level (SLC) & 10 & 5.6 \\
\cline { 2 - 4 } & High School (+2) & 24 & 13.3 \\
\cline { 2 - 4 } & Bachelor & 75 & 41.7 \\
\cline { 2 - 4 } & Master or Higher & 71 & 39.4 \\
\hline \multirow{5}{*}{ Occupation } & Government job employee & 15 & 8.3 \\
\cline { 2 - 4 } & Private job employee & 76 & 42.2 \\
\cline { 2 - 4 } & Self employed/Business owner & 6 & 3.3 \\
\cline { 2 - 4 } & Student & 72 & 40 \\
\cline { 2 - 4 } & Home duties/Unemployed & 7 & 2.2 \\
\cline { 2 - 4 } & Retired & 6 & 3.9 \\
\hline \multirow{5}{*}{ Average income } & Less than Rs 15,000 & 59 & 32.8 \\
\cline { 2 - 4 } & Rs 15,000 to Rs 30,000 & 26 & 14.4 \\
\cline { 2 - 4 } & Rs 30,000 to Rs 45,000 & 75 & 7.8 \\
\cline { 2 - 4 } & More than Rs 45,000 & 41.7 \\
\cline { 2 - 4 } & I do not earn & & 7 \\
\hline
\end{tabular}


The user experience of $3 \mathrm{G}$ mobile utilization analysis reveals $88 \%$ of the sample utilize $3 \mathrm{G}$ mobile service while $12 \%$ don't utilize it. In addition to this, when the respondents are asked for the reasons for using mobile internet service with multiple choice question, the research identifies $76.6 \%$ i.e. 138 used for socializing, $72.2 \%$ i.e. 130 used for entertainment, $70 \%$ i.e. 120 used for education/study, $51.7 \%$ i.e. 93 used for work and $13.9 \%$ i.e. 25 used for shopping.

Among the two major telecom operators in the country, $68 \%$ of the respondents use Nepal Telecom mobile service while $32 \%$ of the respondents use NCell mobile service with 53.9\% subscribing the same operator for more than 3 years. However, low $3 \mathrm{G}$ service utilization is observed as almost $57.2 \%$ users spend less than 30 minutes per day using the service, almost $70 \%$ spend only less than 1 GB per month and among $68.9 \%$ surveyed show willingness to spend is less than NRs 500 (USD $4.69^{2}$ ) per month on $3 \mathrm{G}$ internet service which is relatively low in comparison to that from internet service providers.

On the contrary, Table 6 shows the reasons that bar users for not utilizing the $3 \mathrm{G}$ mobile services. The results show $79.4 \%$ users complaining the excessive usage fee is the major reasons that bars them on utilizing $3 \mathrm{G}$ mobile internet. Beside the mentioned reasons the other reasons for not utilizing $3 \mathrm{G}$ mobile services include the speed and sluggishness of $3 \mathrm{G}$ internet, quick drainage of mobile battery and presence of alternative medium to access the internet via Wi-Fi.

Table 6. Reasons that bars users for not using 3G mobile service

\begin{tabular}{|c|c|c|c|}
\hline Profile & Classification & Frequency & Percent \\
\hline \multirow{6}{*}{$\begin{array}{l}\text { Barriers } \\
\text { for not } \\
\text { using 3G } \\
\text { mobile } \\
\text { service }\end{array}$} & Excessive usage fee. & 143 & 79.4 \\
\hline & Insufficient understanding about the usage. & 36 & 20 \\
\hline & Incompatibility of present mobile phone. & 35 & 19.4 \\
\hline & $\begin{array}{l}\text { Current } 3 \mathrm{G} \text { mobile service is not compliant with } \\
\text { personal need. }\end{array}$ & 19 & 10.6 \\
\hline & Others & 8 & 4.4 \\
\hline & Total & 180 & 100 \\
\hline
\end{tabular}

\subsection{Correlation analysis}

Correlation is a term that refers to the strength of a relationship between two variables. The test is done to determine whether the linear relationship in the sample data effectively models the relationship in the population. Table 7 depicts the correlation analysis done for hypothesis testing.

\footnotetext{
2 Exchange rate for 1 USD was NRs 106.57 as on November 1, 2016
} 
Tuladhar: Influencing Factors for the Acceptance of 36 Mobile Service in Kathmandu Valley

Table 7. Correlation table of influencing factors

\begin{tabular}{|c|l|l|r|r|r|r|r|}
\hline \multicolumn{2}{|c|}{ Correlation Table } & PU & PEOU & ATU & BI & SI & \multicolumn{1}{l|}{ PP } \\
\hline \multirow{2}{*}{ PU } & Pearson Correlation & 1 & $.205^{* *}$ & $.562^{* *}$ & $.314^{* *}$ & 0.066 & $.428^{* *}$ \\
\cline { 2 - 7 } & Sig. (2-tailed) & & 0.006 & 0 & 0 & 0.38 & 0 \\
\hline \multirow{2}{*}{ PEOU } & Pearson Correlation & & 1 & $.392^{* *}$ & $.276^{* *}$ & $.209^{* *}$ & 0.095 \\
\cline { 2 - 8 } & Sig. (2-tailed) & & & 0 & 0 & 0.005 & 0.206 \\
\hline \multirow{2}{*}{ ATU } & Pearson Correlation & & & 1 & $.384^{* *}$ & $.158^{*}$ & $.377^{* *}$ \\
\cline { 2 - 8 } & Sig. (2-tailed) & & & & 0 & 0.035 & 0 \\
\hline \multirow{2}{*}{ BI } & Pearson Correlation & & & & 1 & $.232^{* *}$ & 0.07 \\
\cline { 2 - 8 } & Sig. (2-tailed) & & & & & 0.002 & 0.353 \\
\hline \multirow{2}{*}{ SI } & Pearson Correlation & & & & & 1 & 0.003 \\
\cline { 2 - 8 } & Sig. (2-tailed) & & & & & & 0.972 \\
\hline \multirow{2}{*}{ PP } & Pearson Correlation & & & & & & 1 \\
\cline { 2 - 8 } & Sig. (2-tailed) & & & & & & \\
\hline \multirow{2}{*}{}
\end{tabular}

* Correlation is significant at the 0.05 level (2-tailed).

** Correlation is significant at the 0.01 level (2-tailed).

The following results can be drawn to the stated hypothesis by observing Table 7

$\mathrm{HO}_{1}$ : There is no significant relationship of social influence (SI) on the perceived ease of use (PEOU).

Since the p-value $=0.006<$ level of significance $(\alpha)=0.05$, so we reject the null hypothesis. Thus there is a significant relationship between social influence and perceived ease of use.

$\mathrm{HO}_{2}$ : There is no significant relationship of social influence (SI) on the perceived usefulness (PU).

Since the p-value $=0.38>$ level of significance $(\alpha)=0.05$, so we accept the null hypothesis. Thus there is a no significant relationship between social influence and perceived usefulness.

$\mathrm{HO}_{3}$ : There is no significant relationship of social influence (SI) on the attitude to use (ATU).

Since the p-value $=0.035<$ level of significance $(\alpha)=0.05$, so we reject the null hypothesis. Thus there is a significant relationship between social influence and attitude to use.

$\mathrm{HO}_{4}$ : There is no significant relationship of price perception (PP) on the perceived usefulness (PU). 
Since the p-value $=0<$ level of significance $(\alpha)=0.05$, so we reject the null hypothesis. Thus there is a significant relationship between price perception and perceived usefulness.

$\mathrm{HO}_{5}$ : There is no significant relationship between perceived usefulness (PU) and attitude to use (ATU).

Since the p-value $=0<$ level of significance $(\alpha)=0.05$, so we reject the null hypothesis. Thus there is a significant relationship between perceived usefulness and attitude to use.

$\mathrm{HO}_{6}$ : There is no significant relationship between perceived ease of use (PEOU) and attitude to use (ATU).

Since the p-value $=0<$ level of significance $(\alpha)=0.05$, so we reject the null hypothesis. Thus there is a significant relationship between perceived ease of use and attitude to use.

$\mathrm{HO}_{7}$ : There is no significant relationship between perceived ease of use (PEOU) and Behavioral Intention (BI).

Since the $p$-value $=0<$ level of significance $(\alpha)=0.05$, so we reject the null hypothesis. Thus there is a significant relationship between perceived ease of use and behavioral intention.

$\mathrm{HO}_{8}$ : There is no significant relationship between attitude to use (ATU) and Behavioral Intention (BI).

Since the p-value $=0<$ level of significance $(\alpha)=0.05$, so we reject the null hypothesis. Thus there is a significant relationship between attitude to use and behavioral intention.

$\mathrm{HO}_{9}$ : There is no significant relationship between perceived usefulness (PU) and Behavioral Intention (BI).

Since the p-value $=0<$ level of significance $(\alpha)=0.05$, so we reject the null hypothesis. Thus there is a significant relationship between perceived usefulness and behavioral intention.

\subsection{Analysis of variance}

The one way analysis of variance (ANOVA) is used to determine whether there are any statistically significant differences between the means of three or more independent groups and it thus tests the null hypothesis if the samples drawn from population with the same mean value. The test is being done for age group and BI as shown in Table 8 and between income level and BI as shown in Table 9. 
Tuladhar: Influencing Factors for the Acceptance of $3 G$ Mobile Service in Kathmandu Valley

Table 8. One way ANOVA test between age group and BI

\begin{tabular}{|l|r|r|r|r|r|}
\hline & Sum of Squares & df & \multicolumn{1}{c|}{ Mean Square } & F & \multicolumn{1}{c|}{ Sig. } \\
\hline Between groups & 0.15 & 3 & 0.05 & 0.094 & \multirow{2}{*}{0.963} \\
\cline { 1 - 4 } Within groups & 93.408 & 176 & 0.531 & & \\
\cline { 1 - 5 } Total & 93.559 & 179 & & & \\
\hline
\end{tabular}

Table 9. One way ANOVA test between income level and BI

\begin{tabular}{|l|r|r|r|r|r|}
\hline & Sum of Squares & df & Mean Square & F & Sig. \\
\cline { 1 - 4 } Between groups & 1.122 & 4 & 0.28 & 0.531 & \multirow{2}{*}{0.713} \\
\cline { 1 - 4 } Within groups & 92.437 & 175 & 0.528 & & \\
\cline { 1 - 4 } Total & 93.559 & 179 & & & \\
\hline
\end{tabular}

From Table 8, one way ANOVA test between age group and behavioral intention shows the F-value is 0.094 and $p$-value $=0.963>$ level of significance $(\alpha)=0.05$, so we accept the null hypothesis $\left(\mathrm{HO}_{10 \mathrm{a}}\right)$. Thus there is no significant relationship between age group (DV1) and behavioral intention (BI).

Similarly from Table 9, one way ANOVA test between income level and behavioral intention shows the F-value is 0.531 and $\mathrm{p}$-value $=0.713>$ level of significance $(\alpha)=0.05$, so we accept the null hypothesis $\left(\mathrm{HO}_{10 \mathrm{c}}\right)$. Thus there is no significant relationship between income level and behavioral intention.

\subsection{Independent sample t-test analysis}

The independent sample t-test compares the means of two independent groups in order to determine whether there is statistical evidence that the associated population means are significantly different.

Table 10. Independent sample t-test between gender and behavioral intention

\begin{tabular}{|c|c|c|c|}
\hline & $\mathbf{t}$ & df & Sig. (2-tailed) \\
\hline Equal variances not assumed & -0.329 & 167.507 & 0.742 \\
\hline
\end{tabular}

From Table 10, independent sample t-value between gender and behavioral intention with equal variances not assumed is -0.329 and $\mathrm{p}$-value $=0.742>$ level of significance $(\alpha)=0.05$, so we accept the null hypothesis $\left(\mathrm{HO}_{10 \mathrm{~b}}\right)$. Thus there is no significant relationship between gender (DV2) and behavioral intention (BI).

Table 11 summarizes the result of hypothesis derived from inferential analysis

Table 11. Summary of hypothesis testing

\begin{tabular}{|l|l|l|}
\hline Hypothesis & Statement & Result \\
\hline $\mathrm{HO}_{1}$ & $\begin{array}{l}\text { There is no significant relationship of social influence (SI) } \\
\text { on the perceived ease of use (PEOU). }\end{array}$ & Rejected \\
\hline $\mathrm{HO}_{2}$ & $\begin{array}{l}\text { There is no significant relationship of social influence (SI) } \\
\text { on the perceived usefulness (PU). }\end{array}$ & Accepted \\
\hline
\end{tabular}




\begin{tabular}{|l|l|l|}
\hline $\mathrm{HO}_{3}$ & $\begin{array}{l}\text { There is no significant relationship of social influence (SI) } \\
\text { on the attitude to use (ATU). }\end{array}$ & Rejected \\
\hline $\mathrm{HO}_{4}$ & $\begin{array}{l}\text { There is no significant relationship of price perception (PP) } \\
\text { on the perceived usefulness (PU). }\end{array}$ & Rejected \\
\hline $\mathrm{HO}_{5}$ & $\begin{array}{l}\text { There is no significant relationship between perceived } \\
\text { usefulness (PU) and attitude to use (ATU). }\end{array}$ & Rejected \\
\hline $\mathrm{HO}_{6}$ & $\begin{array}{l}\text { There is no significant relationship between perceived ease } \\
\text { of use (PEOU) and attitude to use (ATU). }\end{array}$ & Rejected \\
\hline $\mathrm{HO}_{7}$ & $\begin{array}{l}\text { There is no significant relationship between perceived ease } \\
\text { of use (PEOU) and Behavioral Intention (BI). }\end{array}$ & Rejected \\
\hline $\mathrm{HO}_{8}$ & $\begin{array}{l}\text { There is no significant relationship between attitude to use } \\
\text { (ATU) and Behavioral Intention (BI). }\end{array}$ & Rejected \\
\hline $\mathrm{HO}_{9}$ & $\begin{array}{l}\text { There is no significant relationship between perceived } \\
\text { usefulness (PU) and Behavioral Intention (BI). }\end{array}$ & Rejected \\
\hline $\mathrm{HO}_{10 \mathrm{a}}$ & $\begin{array}{l}\text { There is no significant relationship between demographic } \\
\text { variable -age (DV1) and Behavioral Intention (BI). }\end{array}$ & Accepted \\
\hline $\mathrm{HO}_{10 \mathrm{~b}}$ & $\begin{array}{l}\text { There is no significant relationship between demographic } \\
\text { variable -gender (DV2) and Behavioral Intention (BI). }\end{array}$ & Accepted \\
\hline $\mathrm{HO}_{10 \mathrm{c}}$ & $\begin{array}{l}\text { There is no significant relationship between demographic } \\
\text { variable -income level (DV3) and Behavioral Intention (BI). }\end{array}$ & Accepted \\
\hline
\end{tabular}

\section{Concluding Remarks}

The model has taken six variables interrelated as in the conceptual framework of extended TAM ultimately leading to acceptance or rejection of $3 \mathrm{G}$ mobile service. The primary conclusion drawn from the findings is that social influence, price perception, perceived ease of use, perceived usefulness and attitude to use are the factors that influence the behavioral intention to use $3 \mathrm{G}$ mobile service which finally determines the acceptance or rejection of the service. The research also finds the interrelationship between the determinants as well. The significant relationship between social influence and perceived ease of use justifies that Kathmandu Valley mobile users tend to believe the use of technology is easier when they observe their social circles utilize them more often. However indifferent view for perceived usefulness in terms of social influence states that the way the people use $3 \mathrm{G}$ differs from people to people so usefulness of utilization cannot be drawn from social influence as drawn for perceived ease of use. Also, perceived usefulness and price perception are positively related which signify if mobile operator reduces their price, people are likely to perceive utilization of $3 \mathrm{G}$ mobile internet is useful.

Perceived usefulness and perceived ease of use influence the attitude of use, which finally triggers the behavioral intention to use, which is consistent with the stated theory of the acceptance model. This signifies that the positive attitude towards use 
of $3 \mathrm{G}$ service is developed when the service is useful as well as user friendly. Along with this, social influence and price perception are also found to be the extended factors that can influence the attitude of the users, which in turn affects the behavioral intention. Demographic variables, however in this study, have shown no significant influence on the behavioral intentions. Age, gender and income level, which are taken as the demographic variable, are proven to be indifferent in this study.

The cognitive process for acceptance of $3 \mathrm{G}$ mobile services in Kathmandu Valley follows the conceptual model, which draws the primary fact that the service must be useful as well as easy to understand. Thus, mobile service providers must develop ease of use with easy device settings configuration and simplistic data package purchase schemes. It is suggested to service providers to focus more on social media marketing and customer support services as the subscriber's recommendations to their family, friends and among their social circle significantly boost the positive attitude towards using the service. Along with this, pricing can be taken as a sensitive strategy that mobile service provider needs to analyze carefully. Overpriced service develops negative attitude to use. Similarly, dissatisfaction among users is seen when the expected benefits and services are not met with the price they pay which ultimately results in denial in using the service. For mobile phone manufacturers the qualitative information from the study suggests that quick drainage of battery and sluggish processor speed of the device restrict users to accept the $3 \mathrm{G}$ mobile phones and its services. Thus, manufactures must incorporate their product design criteria with sufficient battery backup, greater processor speed and smooth functioning as this has become a minimum system requirement in today's context.

\section{References}

Abu, S. T. (2010). Technological innovations and $3 \mathrm{G}$ mobile phone diffusion: Lessons. Telematics and Informatics, Vol. 27, 418-432.

Agarwal, N. K., Wang, Z., Xu, Y., \& Poo, D. C. (2007). Factors affecting 3G adoption: An empirical study. 11th Pacific-Asia Conference on Information Systems, 256-270.

Ajzen, I. (1991). The theory of planned behavior. Organizational Behavior and Human Decision Processes, Vol. 50(2), 179-211.

Ajzen, I., \& Fishbein, M. (1980). Understanding attitude and predicting social behaviour. $1^{\text {st }}$ Edition, Englewood-Cliffs, Prentice-Hall. 
Chong, A., Ooi, K., Lin, B., \& Bao, H. (2012). An empirical analysis of the determinants of $3 \mathrm{G}$ adoption in China. Computers in Human Behavior, Vol. 28 (2), 360-369.

Davis, F. D. (1989). Perceived usefulness, perceived ease of use, and user acceptance of Information technology. MIS Quarterly, Vol. 13 (3), 319-340.

Davis, F., \& Venkatesh, V. (2000). A theoretical extension of the technology acceptance mode: Four longitudinal field studies. Management Science, Vol. 46(2), 186-204.

Garg, D., \& Garg, A. K. (2013). An assessment of $3 \mathrm{G}$ internet service acceptance in Botswana: technology acceptance model with social influence and orice perception. Pakistan Journal of Social Sciences, Vol. 33(1), 47 -60.

Jongepier, J. (2011). Young adopters of smartphones: Examining determinants of the adoption decision. An unpublished MA thesis sumbitted to Erasmus University Rotterdam, the Netherlands.

Kaasinen, E. (2005). User acceptance of mobile services - value, ease of use, trust and ease of adoption. A published doctor of technology thesis submitted to Tampere University of Technology. Vtt publications.

Kumar, S. \& Sikri, V. (2013). The role of moderating factors of 3G user acceptance technology in Shimla. (2013). International Journal of Advanced Research in Computer Science and Software Engineering, Vol. 3(5), 1090-1094.

Kuo, Y.-F., \& Yen, S.-N. (2009). Towards an understanding of the behavioral intention to use $3 \mathrm{G}$ mobile value-added services. Computers in Human Behavior, Vol. 25 (1), 103-110.

Liu, Y., \& Li, H. (2010). Mobile internet diffusion in China: An emperical study. Industrial Management and Data System, Vol. 110(3), 309-324.

Mahfuz, T., \& Latif, S. (2013). An assessment of 3G mobile service acceptance in Bangladesh. International journal of advanced computer science and applications, Vol. 4 (11), 140-143.

Malhotra, Y., \& Galletta, D. (1999). Extending the technology acceptance model to account for social influence:. Proceedings of the 32nd Hawaii International Conference on System Sciences, 1-14

Mardikyan, S., Beşiroğlu, B., \& Uzmaya, G. (2012). Behavioral Intention towards the use of $3 \mathrm{G}$ technology. Communications of the IBIMA, Vol. 1, 1-10. 
Pan, T. (2011). Factors affecting mobile gaming adoption - A study of chinese users and context. An unpublished masters of marketing thesis submitted to Department of Marketing, Aalto University.

Phuangthong, D., \& Malisawan, S. (2005). A study of behavioral intention for 3G mobile internet. Proceedings of the Second International Conference on eLearning for Knowledge-Based Society, 17(1)-17.7, August 5-7, Thailand.

Phuong, N., Van, T., \& An, N. (2015). Understanding 3G mobile service acceptance in Ho Chi Minh City. International Journal of Business and Management, Vol. 10(4), 70-81.

Singh, S., \& Singh, M. (2010). The forecasting of $3 \mathrm{G}$ market in India. International Journal of Next-Generation Networks, Vol. 2 (2), 61-68.

Suki, N. M. (2012). Third generation (3G) mobile service acceptance: Evidence from Malaysia. African Journal of Business Management, Vol. 6(15), 5165-5171.

Susilo, A., \& Dahesihsari, R. (2011). Perceived Usefulness as Key Stimulus to the Behavioral. ASEAN Marketing Journal, Vol. 3 (2), 105-114.

Viswanath, V., Morris, M., Davis, G., \& Davis, F. (2003). User acceptance of information techonlogy: Toward a unified view. MIS Quartely, Vol. 27(3), 425-478. 